Support statement: the ECLIPSE study was sponsored by GlaxoSmithKline. The study sponsor did not place any restrictions on statements made in the final paper. Funding information for this article has been deposited with FundRef.

Conflict of interest: Disclosures can be found alongside the online version of this article at erj.ersjournals.com

\title{
References
}

1 Rutten EP, Bakke P, Pillai S, et al. The association between body composition and self-reported co-morbidity in subjects with chronic obstructive pulmonary disease. Open J Intern Med 2012; 2: 100-106.

2 Vestbo J. Clinical assessment, staging, and epidemiology of chronic obstructive pulmonary disease exacerbations. Proc Am Thorac Soc 2006; 3: 252-256.

3 Seymour JM, Spruit MA, Hopkinson NS, et al. The prevalence of quadriceps weakness in COPD and the relationship with disease severity. Eur Respir J 2010; 36: 81-88.

4 Vanfleteren LE, Spruit MA, Groenen M, et al. Clusters of comorbidities based on validated objective measurements and systemic inflammation in patients with chronic obstructive pulmonary disease. Am J Respir Crit Care Med 2013; 187: 728-735.

5 Vestbo J, Prescott E, Almdal T, et al. Body mass, fat-free body mass, and prognosis in patients with chronic obstructive pulmonary disease from a random population sample: findings from the Copenhagen City Heart Study. Am J Respir Crit Care Med 2006; 173: 79-83.

6 van den Borst B, Koster A, Yu B, et al. Is age-related decline in lean mass and physical function accelerated by obstructive lung disease or smoking? Thorax 2011; 66: 961-969.

7 Rutten EPA, Calverley PM, Casaburi R, et al. Changes in body composition in patients with chronic obstructive pulmonary disease: do they influence patient related outcomes? Ann Nutr Metab 2013; 63: 239-247.

8 Vestbo J, Anderson W, Coxson HO, et al. Evaluation of COPD Longitudinally to Identify Predictive Surrogate End-points (ECLIPSE). Eur Respir J 2008; 31: 869-873.

9 Steiner MC, Barton RL, Singh SJ, et al. Bedside methods versus dual energy X-ray absorptiometry for body composition measurement in COPD. Eur Respir J 2002; 19: 626-631.

10 Anker SD, Coats AJ, Morley JE, et al. Muscle wasting disease: a proposal for a new disease classification. J Cachexia Sarcopenia Muscle 2014; 5: 1-3.

11 Hopkinson NS, Tennant RC, Dayer MJ, et al. A prospective study of decline in fat free mass and skeletal muscle strength in chronic obstructive pulmonary disease. Respir Res 2007; 8: 25.

12 Wan ES, Cho MH, Boutaoui N, et al. Genome-wide association analysis of body mass in chronic obstructive pulmonary disease. Am J Respir Cell Mol Biol 2011; 45: 304-310.

13 Harik-Khan RI, Fleg JL, Wise RA. Body mass index and the risk of COPD. Chest 2002; 121: 370-376.

14 Lamprecht B, McBurnie MA, Vollmer WM, et al. COPD in never smokers: results from the population-based burden of obstructive lung disease study. Chest 2011; 139: 752-763.

15 Seeley RJ, Sandoval DA. Neuroscience: weight loss through smoking. Nature 2011; 475: 176-177.

16 Kyle UG, Bosaeus I, De Lorenzo AD, et al. Bioelectrical impedance analysis - part I: review of principles and methods. Clin Nutr 2004; 23: 1226-1243.

\section{Diagnosis of COPD before cardiac surgery}

To the Editor:

We recently performed a retrospective study of the utility of respiratory function tests prior to cardiac surgery at our hospital. The study aimed to identify whether an association exists between pre-operative respiratory function tests and post-operative outcomes. The study also aimed to determine how the definition of chronic obstructive pulmonary disease (COPD) by Global Initiative in Chronic Obstructive Lung Disease (GOLD) [1] or by lower limit of normal (LLN) [2] may alter peri-operative management.

Between January 2011 and January 2014, 1330 patients underwent cardiac surgery at Holy Spirit Northside Private Hospital (HSNPH), Brisbane, Australia, a private hospital facility operating as part of the St Vincent's Health Australia group. Of this number, 289 mainly symptomatic patients were referred for respiratory function tests which were performed at HSNPH within 3 days of admission. The patients then proceeded with the intended cardiac surgery.

A patient was classified as COPD (GOLD) if the ratio of forced expiratory volume (FEV1) to forced vital capacity (FVC) was $<0.70$ [1]. A patient was classified as COPD (LLN) if the FEV1/FVC ratio was <LLN. The LLN criteria identify the fifth percentile of the study population, defined as 1.645 relative standard deviations below the mean predicted value [2]. The Global Lung Function Initiative 2012 equations were used to calculate predicted values and z-scores for spirometry [3]. 
125 patients (43\% of the cohort) were classified as having COPD by the GOLD criteria (hereafter referred to as GOLD) and only $45.6 \%$ of these ( $n=57 ; 19.7 \%$ of the cohort) were also classified as COPD by the LLN criteria (hereafter referred to as LLN). Table 1 shows the demographics for the GOLD and LLN groups compared to controls (non-COPD) group $(\mathrm{n}=164)$.

Of the 289 subjects in the study, eight (2.8\%) died within 30 days of their surgery and six (2.1\%) had pneumonia in the post-operative period. Seven of the eight deaths occurred in hospital and one death occurred after discharge to a rehabilitation facility.

Patients with COPD defined by either GOLD or LLN criteria had longer intubation time, longer intensive care unit (ICU) stay and longer length of hospital stay than patients in the control group. Interestingly, only patients with COPD defined by LLN criteria $(n=57)$ had higher mortality and pneumonia than the control group.

Patients with COPD as defined by the LLN criteria $(n=57)$ had a lower FEV1 $(p<0.001)$ and lung transfer factor for carbon monoxide $(\mathrm{p}<0.001)$ compared to patients with COPD defined by GOLD criteria $(\mathrm{n}=125)$.

Patients in the discordant group which comprised those with COPD defined by GOLD criteria but not by LLN criteria (COPD GOLD only) $(n=68)$ did have a longer intubation time $(\mathrm{p}=0.003)$ and a longer length of stay in ICU $(p=0.014)$ than patients in the control group $(n=164)$. However, there was no difference in length of stay in hospital compared to the control group $(\mathrm{p}=0.084)$. When assessed by logistic regression, patients with COPD GOLD only $(n=68)$ showed no difference in the risk of death and/or pneumonia when compared to those in the control group ( $\mathrm{n}=164)$ (OR 2.45, 95\% CI 0.34-17.79; $\mathrm{p}=0.37$ ). In comparison, having COPD as defined by LLN criteria $(n=57)$ was associated with a 9.53-fold (95\% CI 1.86-48.68; $\mathrm{p}=0.007$ ) increased risk of death and/or pneumonia following cardiac surgery compared to those in the control group.

Patients with COPD defined by either GOLD or LLN criteria were significantly older than those in the control group (mean 72.5, 71.9 and 67.5 years, respectively). Considering that FEV1/FVC ratio declines as part of normal ageing processes [3-5], COPD defined by GOLD criteria alone has the potential to "over-diagnose" COPD in elderly patients [4-11]. Indeed, 125 patients (43\%) in our study group could have been diagnosed as having COPD by GOLD criteria, compared with only 57 patients (20\%) by LLN criteria $(p<0.001)$. It is likely that the use of COPD (LLN) criteria would identify patients with genuine disease, whereas using COPD (GOLD) criteria would lead to the inclusion of patients who are healthy, elderly patients. A false diagnosis of COPD by GOLD criteria could lead to some elderly patients being denied potentially useful surgery for serious cardiac problems.

The use of LLN criteria rather than GOLD criteria to diagnose COPD prior to cardiac surgery is likely to reduce the number of elderly patients who would be labelled as having COPD. This could potentially

TABLE 1 Demographics for the Holy Spirit Northside Private Hospital study group with comparisons to the control group las assessed by t-test)

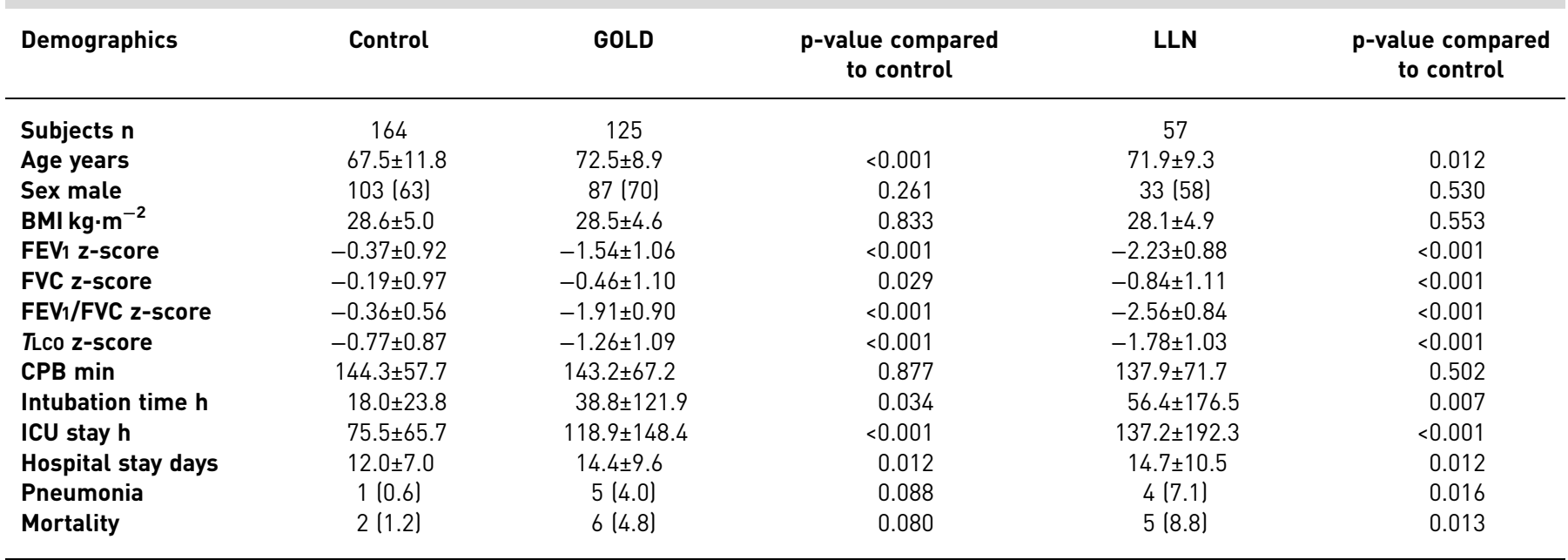

Data are presented as mean \pm SD or $\mathrm{n}(\%)$, unless otherwise stated. GOLD: Global Initiative for Chronic Obstructive Lung Disease; LLN: lower limit of normal; BMI: body mass index; FEV1: forced expiratory volume in $1 \mathrm{~s}$; FVC: forced vital capacity; TLCo: lung transfer factor for carbon monoxide; CPB: cardiopulmonary bypass; ICU: intensive care unit. 
avoid unnecessary drug treatment of COPD in these patients and thus ameliorate costs and reduce side-effects from $\beta_{2}$-agonists. In a population of patients with cardiac disease, it may be an advantage to avoid $\beta_{2}$-agonists, as they can cause tachy-arrhythmias and exacerbation of angina [12-14]. A future study examining both the utility and cost of drug treatment for COPD and the cost savings that could be made by using LLN criteria to diagnose COPD would be very interesting.

Based on our study, we recommend the use of LLN criteria rather than GOLD criteria to diagnose COPD prior to cardiac surgery. The use of LLN criteria may reduce the "over-diagnosis" of COPD in elderly patients and may reduce costs and side-effects from unnecessary treatment of "COPD" and better identify those at risk of poor outcomes following surgery. than COPD defined by GOLD http://ow.ly/QvAPn

Nicholas J. McKeon ${ }^{1}$, Sjane N. Timmins ${ }^{1}$, Heather Stewart ${ }^{1}$, Stephanie T. Yerkovich ${ }^{2}$ and James L. McKeon ${ }^{1}$

${ }^{1}$ Holy Spirit Lung Function Laboratory, Holy Spirit Northside Private Hospital, Brisbane, Australia. ${ }^{2}$ Dept of Thoracic Medicine, The Prince Charles Hospital, Brisbane, Australia.

Correspondence: James McKeon, Holy Spirit Northside Private Hospital rooms, 627 Rode Road, Chermside, Queensland, 4032, Australia. E-mail: mckeonjl@bigpond.com.au

Received: Sept 302014 | Accepted after revision: June 152015 | First published online: Aug 202015

Conflict of interest: None declared.

\section{References}

1 Vestbo J, Hurd SS, Agusti AG, et al. Global strategy for the diagnosis, management, and prevention of chronic obstructive pulmonary disease: GOLD executive summary. Am J Respir Crit Care Med 2013; 187: 347-365.

2 Pellegrino R, Viegi G, Brusasco V, et al. Interpretative strategies for lung function tests. Eur Respir J 2005; 26 : 948-968.

3 Quanjer PH, Stanojevic S, Cole TJ, et al. Multi-ethnic reference values for spirometry for the 3-95 years age range: the Global Lung Function 2012 equations. Eur Respir J 2012; 40: 1324-1343.

4 Gibson GJ. Clinical Tests of Respiratory Function. Chapter 3. London and Basingstoke, The Macmillan Press Ltd, 1982.

5 Güder G, Brenner S, Angermann CE, et al. GOLD or lower limit of normal definition? A comparison with expert-based diagnosis of chronic obstructive pulmonary disease in a prospective cohort-study. Respir Res 2012; 13: 13.

6 Wang Y, Xiao W, Ma DD, et al. Predicted lower limit of normal reduces misclassification risk of airflow limitation in asymptomatic elderly never-smokers. Chin Med J 2013; 126: 3486-3492.

7 Hwang YI, Kim CH, Kang HR, et al. Comparison of the prevalence of chronic obstructive pulmonary disease diagnosed by lower limit of normal and fixed ratio criteria. J Korean Med Sci 2009; 24: 621-626.

8 Hardie JA, Buist AS, Vollmer WM, et al. Risk of over-diagnosis of COPD in asymptomatic elderly never-smokers. Eur Respir J 2002; 20: 1117-1122.

9 Swanney MP, Ruppel G, Enright PL, et al. Using the lower limit of normal for the $\mathrm{FEV}_{1} / \mathrm{FVC}$ ratio reduces the misclassification of airway obstruction. Thorax 2008; 63: 1046-1051.

10 Celli BR, Halbert RJ, Isonaka S, et al. Population impact of different definitions of airway obstruction. Eur Respir J 2003; 22: 268-273.

11 Hansen JE, Sun XG, Wasserman K. Spirometric criteria for airway obstruction: Use percentage of FEV1/FVC ratio below the fifth percentile, not $<70 \%$. Chest 2007; 131: 349-355.

$12 \mathrm{Au}$ DH, Curtis JR, Every NR, et al. Association between inhaled beta-agonists and the risk of unstable angina and myocardial infarction. Chest 2002; 121: 846-851.

13 Appleton SL, Ruffin RE, Wilson DH, et al. North West Adelaide Cohort Health Study Team. Cardiovascular disease risk associated with asthma and respiratory morbidity might be mediated by short-acting beta2-agonists. J Allergy Clin Immunol 2009; 123: 124-130.

14 Salpeter SR, Ormiston TM, Salpeter EE. Cardiovascular effects of $\beta$-agonists in patients with asthma and COPD a meta-analysis. Chest 2004; 125: 2309-2321. 